\title{
CD11c Negative
}

National Cancer Institute

\section{Source}

National Cancer Institute. CD11c Negative. NCI Thesaurus. Code C162060.

An indication that CD11c expression has not been detected in a sample. 